\title{
UPACARA TETEK PANTAN DI KABUPATEN KOTAWARINGIN TIMUR
}

\author{
Sulandra
}

\begin{abstract}
Ritual is a very important thing for Dayak people. If done sincerely, rituals can increase motivation and life balance. Of the many rituals, Dayak people have a ritual called Pantan. Tetek Pantan is a welcome ritual to the honor guest. Pantan can be interpreted as a barrier tree. In the implementation of the ritual, the Pantan is cut as a sign of the guest has been well received. Potong Pantan or Tetek Pantan ritual is cutting, dispelling nightmares, distractions and obstacles. Thus, guests will be protected from God, Health, Longevity, and success
\end{abstract}

Keywords: The form of ritual Tetek Pantan, the function of ritual Tetek Pantan, the meaning of ritual Tetek Pantan

\section{Pendahuluan}

Zaman globalisasi tentunya akan membawa angin perubahan terhadap kehidupan bermasyarakat, hubungan masyarakat Indonesia yang berpedoman pada budaya Pancasila harus siap menghadapi kekuatan global ini, agar tetap eksis sebagai masyarakat pemegang budaya dan bangsa religius.

\section{Kalimantan Tengah yang} merupakan bagian dari bangsa Indonesia yang dihuni oleh berbagai suku, ras, golongan dan agama yang homogen, memiliki berbagai macam kegiatan upacara yang bernuansakan adat dan budaya yang harus selalu dijunjung tinggi dan dilestarikan oleh seluruh masyarakat Kalimantan Tengah, dengan jalan terus melaksanakan dan berupaya selalu mempertahankan upacara tersebut sehingga tidak tercabut dari nilainilai budayanya. Sehingga para penerus generasi muda Dayak sebagai penghuni asli suku di pulau Kalimantan ini tetap eksis menjalankan dan mempertahankan upacara-upacara yang bernuansakan adat-istiadat dan budaya tersebut.

Di dalam pandangan orang dayak, Hidup ini sangat penting mengadakan upacara atau ritual guna 
meningkatkan motivasi hidupnya, dan selalu dijalankan dengan tulus iklas sehingga terdapat keseimbangan didalam kehidupan ini. Pada saat-saat itu manusia merasa perlu melakukan sesuatu untuk memperteguh imannya, yang dilakukannya dengan upacara (Koentjaraningrat, 2002:197).

Di Kalimantan Tengah terdapat suatu upacara yang sering dilaksanakan yaitu upacara pantan yaitu upacara pada saat penyambutan tamu yang dianggap dihormati dan ditokohkan oleh masyarakat. Pantan bisa diartikan sebagai pohon penghalang atau kayu perintang, melakukan pemotongan pantan biasanya dipergunakan dalam menyambut tamu-tamu Pejabat atau tamu terhormat dari luar daerah atau menyambut para pahlawan yang baru pulang dari medan peperangan dengan membawa kemenangan. Acara manetek pantan mengandung dua makna yaitu: sebagai rasa kebanggaan dan rasa suka cita.

Acara pantan adalah memotong, mengusir, menghalau firasat-firasat buruk, mimpi buruk, gangguan penghalang dan rintangan .
Sehingga para tamu yang memotong pantan selalu mendapat per perlindungan dari Pencipta Alam Semesta atau Yang Maha Kuasa, sehingga para tamu tadi mendapat kesehatan, diperpanjangkan umur, dimurahkan rejeki dan dalam menjalankan tugas mendapat kesuksesan.

Upacara Pantan ini sangat perlu sekali dikembangkan demi mengangkat Seni Budaya Dayak, nilai-nilai leluhur Nenek Moyang, supaya tetap berurat berakar kuat dan kokoh dimasyarakat Dayak khususnya dan menjalin suatu persatuan kesatuan suku, Bangsa Indonesia pada umumnya.

Upacara penyambutan tamu atau pantan ini semakin hari dirasakan semakin jarang ditemui, hal ini dimungkinkan karena semakin terbukanya akses transportasi dan akses informasi sehingga terlihat bahwa upacara tersebut semakin dilupakan dan hampir-hampir hilang. Sementara kita ketahui bahwa upacara penyambutan tamu atau pantan tersebut tentunya mempunyai nilainilai yang fositif didalamnya. 
Namun seiring dengan berjalannya arus globalisasi yang mana telah membuat generasi muda suku dayak terlena didalam perubahan tersebut, sehingga mereka tidak mengetahui tata cara pelaksanaan upacara-upacara yang diwarisi oleh nenek moyang kita dahulu.

\section{Pembahasan}

\subsection{Upacara Pantan}

Upacara apabila dilihat dari asal katanya , berasal dari upa dan cara yang mempunyai arti upa berarti berhubungan dengan dan cara gerakan, jadi yang dimaksud dengan upacara adalah segala sesuatu yang ada hubungannya dengan gerakan atau kegiatan, atau dengan kata lain upacara adalah gerakan (pelaksanaan) daripada salah satu Yadnya (Surayin:2004).

Dalam kamus besar Bahasa Indonesia yang dimaksud dengan upacara adalah peralatan (menurut adat iatiadat); rangkaian tindakan atau perbuatan yang terikat pada aturan tertentu menurut adat atau agama. (Tim:2005).
Yadnya adalah berasal dari kata Yaj (bahasa Sansekerta) yang berarti memuja atau pemujaan. Yadnya berarti upacara korban suci (Adiputra, dkk:2004). Sebagai suatu pemujaan suci, maka Yadnya memerlukan dukungan sikap mental yang suci pula, disamping adanya sarana yang akan dipersembahkan.. Sarana yang melengkapi pelaksanaan suatu yadnya inilah yang disebut dengan upakara/sajen. Secara etimologi upakara mengandung pengertian pelayanan yang ramah tamah atau kebaikan hati. Bertolak dari pengertian itu setiap upakara yang dipersembahkanpatut didasari dengan ketulusan, kemantapan dan kesucian hati yang ditampilkan dalam sikap dan perilaku yang mencerminkan keramahtamahan dan kebaikan hati.

\section{Di Kalimantan Tengah} terdapat berbagai jenis ritual, adat dan budaya yang diyakini dan dilaksanakan oleh masyarakat Suku Dayak di Kalimantan Tengah, salah satunya adalah upacara yang dilakukan dalam rangka menyambut tamu yaitu diadakan Upacara Pantan. Acara pantan atau tetek 
pantan secara filosofis yaitu pada saat sebelum dipersilahkan masuk kepada tamu kehormatan disucikan/ dipapas supaya dijauhkan dari pengaruh negative dan selalu mendapat perlindungan dari Pencipta Alam Semesta atau Yang Maha Kuasa, sehingga para tamu tadi mendapat kesehatan, diperpanjangkan umur, dimurahkan rejeki dan dalam menjalankan tugas untuk mendapat kesuksesan

\subsection{Bentuk Upacara Tetek Pantan} (Penyambutan

Tamu

\section{Kehormatan)}

Latar belakang dari pelaksanaan upacara Tetek Pantan Pada Masyarakat di Kabupaten Kotawaringin Timur adalah merupakan suatu tradisi yang turun temurun dilakukan oleh suku dayak, dimana zaman dahulu pada saat suku dayak masih belum bersatu saling terpisah antara suku yang satu dengan suku yang lainnya, maka sering terjadi peperangan antar suku, untuk menghormati para pejuang yang pulang dengan gagah perkasa dari medan perang, maka masyarakat pada suku tersebut menyambut mereka dengan upacara Pantan.
Sebagai lambang kehormatan atas perjuangan mereka dan telah kembali ke kampung halaman mereka dengan membawa kemenangan. Kemudian akibat dari perubahan zaman dan peperangan antar suku sudah tidak pernah terjadi lagi dan akibat dari perubahan sosial maka upacara tetek pantan dewasa ini adalah dilakukan untuk menyambut tamu kehormatan atau tamu yang datang kewilayah tersebut yang dianggap oleh masyarakat setempat sebagai tamu penting dan dihormati oleh mereka.

Dengan melaksanakan Upacara Tetek Pantan ini merupakan bentuk penghormatan masyarakat Suku Dayak kepada tamu yang mau berkunjung ketempat mereka. Upacara Tetek Pantan ini juga merupakan suatu simbol untuk menghilangkan segala pantangan dan rintangan yang akan menganggu kedatangan tamu tersebut.

Bahwa yang melatar belakangi adanya upacara Pantan (Penyambutan Tamu Kehormatan) di Kabupaten Kotawaringin Timur adalah akibat dari perubahan sosial yang terjadi pada masyarakat dayak 
dimana pada awalnya upacara tetek pantan hanya dilakukan apabila menyambut para pejuang yang pulang dari peperangan dengan membawa kemenangan yang dilakukan dengan upacara tetek pantan kayu, maka sekarang upacara tetek pantan juga dilakukan untuk menyambut orang-orang atau tamu yang dianggap terhormat dan penting bagi daerah mereka.

Berdasarkan hal tersebut, maka yang melatar belakangi pelaksanaan upacara tetek pantan pada masyarakat di Kabupaten Kotawaringin Timur adalah merupakan warisan turun temurun yang dilakukan oleh leluhur suku dayak, yang mana pada dahulu kala tetek pantan tersebut dilakukan jika para pejuang yang berangkat perang polang kembali kekampung halaman mereka dengan membawa kemenangan.

Didalam pelaksanaan upacara pantan pada penyambutan tamu terdapat berbagai berbagai rangkaian acara seperti menginjak telur ayam kampung yang diletakkan diatas batu asah, mamapas dengan daun tangkawang papas, tampung tawar serta kajang galas yang dipimpin oleh pemangku adat atau orang yang dituakan di wilayah tersebut. Bentuk dalam Kamus Besar Bahasa Indonesia (Depdikbud 1988:103104) dijelaskan artinya sebagai "Wujud yang ditampilkan " selain juga berarti sistem susunan (pemerintahan, perserikatan, dan sebagainya), dan bangun, gambaran. Bentuk merupakan sebuah istilah inklusif yang memiliki beberapa pengertian.

Dalam seni dan perancangan, istilah bentuk seringkali dipergunakan untuk menggambarkan struktur formal sebuah pekerjaan yaitu cara dalam menyusun dan mengkoordinasi unsur-unsur dan bagian-bagian dari suatu komposisi untuk menghasilkan suatu gambaran nyata.

Bentuk dapat dihubungkan baik dengan struktur internal maupun garis eksternal serta prinsip yang memberikan kesatuan secara menyeluruh. Dalam konteks penelitian ini pembahasan bentuk diarahkan pada gambaran dan wujud yang ditampilkan dalam Upacara Pantan di Kabupaten Kotawaringin 
Timur. Bentuk dari pelaksanaan upacara Tetek Pantan adalah pertama-tama yang harus dipersiapkan adalah membuat pantan ditempat pelaksanaan upacara tersebut dengan segala atributnya seperti hiasan-hiasan bunga-bungaan dan sekeliling pantan ditutupi dengan kain panjang selanjutnya juga dipersiapkan sarana dan prasarananya seperti Tampung Papas, telur ayam kampung, batu asah, tampung tawar. Setelah semuanya telah siap dan para tamu telah tiba didepan pantan, maka selanjutnya pemimpin upacara biasanya adalah Demang Kepala Adat setempat berdiri didepan pantan tersebut, selanjutnya di depan pantan di letakan satu butir telur ayam kampung yang diletakkan diatas batu asah, terus telur ayam kampung tersebut dipersilahkan kepada pemimpin rombongan untuk menginjakkan telur tersebut sampai pecah dengan menggunakan kaki kanan, disertai doa-doa yaitu seperti telur yang diinjak tersebut supaya para tamu apabila mengijak tanah didaerah tersebut seperti menginjak tanah didaerah mereka saja, dan seperti dinginnya telur ayam tersebut dingin juga kehidupan mereka di daerah tersebut. Setelah selesai acara menginjak telur ayam selanjutnya mengadakan dialog dengan para tamu atau perwakilan dari tamu yang datang.

Sebelumnya pemimpin upacara menjelaskan apa maksud diadakan upacara Pantan tersebut kepada para tamu. selanjutnya dialog dilanjutkan yang mana pemimpin upacara memberikan pertanyaan menanyakan nama-nama tamu yang datang, jumlahnya berapa orang serta apa maksud dan tujuan kedatangan para tamu ke daerah mereka tersebut, kemudian perwakilan tamu menjelaskan nama-nama mereka yang datang tersebut serta menjelaskan maksud dan tujuan kedatangan mereka. Setelah selesai kemudian pemimpin upacara menyerahkan sebelah Mandau (senjata khas Kalimantan) kepada pemimpin rombongan tamu dan mempersilahkan kepada pimpinan rombongan untuk memotong pantan yang menghalangi perjalanan mereka. Maka pemimpin rombongan mulai memotong pantan dengan 
arahan dari pemimpin upacara, pada awalnya pantan tersebut dipotong ke arah matahari tenggelam atau terbenam, pemimpin upcara sambil mengucapkan mantra kupotong pantan ke arah pambelep (matahari tenggelam) supaya belep (tenggelam) pula segala sial kawe pali endus dahiang baya (segala sial pantangan hidup) para rombongan tamu yang datang.

\section{Selanjutnya dipersilahkan} lagi memotong pantan kesebelah pambelum (matahari terbit), dengan diiringi doa-doa supaya belum panjang umur aseng, tatau sanang ngureh ngalawan seperti matahari yang terbit, terbit juga segala harta kekayaan hidup para tamu yang datang, supaya panjang umur dan sehat selalu. Kemudian dipotong bagian bawah supaya jauh dari marabahaya dan hidup tenang, damai, selanjutnya dipotong kebagian atas, supaya hidup kita semuanya selalu berada diatas, hidup penuh wibawa dan mampu mengayomi orang lain.Selanjutnya pemimpin upacara mempersilahkan kepada pimpinan rombongan untuk memotong pantan tersebut sampai terpotong semua.

Setelah pantan tersebut terpotong semuanya dilanjutkan dengan pemimpin upacara memapas para tamu dengan daun tangkawang papas dengan disertai doa-doa untuk membersihkan para tamu dari segala sial dan pantangan hidup, memberikan para tamu kebahagiaan dan harta kekayaan yang melimpah serta selalu diberikan kesehatan. Setelah acara mamapas selesai, maka rombongan tamu dipersilahkan untuk masuk kedaerah atau ketempat tersebut. Maka upacara Tetek Pantan telah selesai.

\subsection{Fungsi Upacara Tetek Pantan}

Upacara Tetek Pantan Dalam Upacara Penyambutan Tamu kiranya memiliki fungsi yang luhur dan sakral bagi kehidupan manusia didunia ini didalam meningkatkan kualitas diri dan kualitas jati diri. Didalam upacara Tetek Pantan ini dapat dilihat dari berbagai fungsi yang terkandung didalamnya yang meliputi fungsi sosial, religius, etika dan fungsi pendidikan. 
Fungsi social dalam upacara Tetek Pantan dalam Upacara Penyambutan tamu juga tercermin pada saat persiapan upacara, dimana seluruh anggota masyarakat suatu desa yang akan dikunjungi berkumpul dan bersama-sama atau bergotong royong untuk mempersiapkan sarana dan prasarana yang diperlukan untuk keperluan upacara upacara tersebut.

Gotong Royong atau bekerja sama antar sesama masyarakat adalah merupakan tradisi turun temurun yang telah diwarisi oleh masyarakat Indonesia pada umumnya dan masyarakat

Kalimantan Tengah pada khususnya. Upacara Tetek Pantan juga berfungsi sebagai suatu wahana masyarakat untuk melaksanakan Yajna kepada sesama manusia (manusia yajna) yaitu tuan rumah dengan penuh kesadaran dan keikhlasan untuk memberikan penghormatan kepada pihak tamu yang berkunjung kedaerah mereka untuk membantu segala kegaiatan demi keberhasilan bersama. Selanjutnya fungsi sosialnya adalah dengan memberikan yajna tersebut maka telah mencerminkan dan

mengimplementasikan ajaran kebaikan baik antara sesama maupun dengan mahluk yang ada dimuka bumi ini. Dengan terselenggaranya upacara Tetek Pantan maka akan menciptakan sistem kekerabatan baru yang mungkin dulunya antara kedua belah pihak tidak saling kenal, maka setelah terjadinya upacara Tetek Pantan akan saling kenal dan saling membutuhkan.

Berdasarkan dari uraian diatas, maka dapat disimpulkan bahwa fungsi sosial yang terkandung didalam upacara Tetek Pantan tersebut adalah sangat tinggi, dimana dengan diadakannya upacara tersebut akan membuat suasana menjadi damai, harmonis, menciptakan suasana gotong royong, saling hormat menghormati, melambangkan sikap persaudaraan serta akan menambah suatu kekerabatan baru dengan tamu yang datang kedaerah tersebut.

fungsi religius Upacara Pantan adalah Upacara yang dilakukan dengan rasa bakti dan kepercayaan yang tinggi tentunya akan bermakna terhadap pengaruh 
atau membangkitkan rasa Ketuhanan terhadap segala sesuatu yang bersifat sacral, sehingga dengan adanya kasih Tuhan manusia akan merasakan rahmatNya. Didalam pelaksanaan Upacara Tetek Pantan tersebut pemimpin upacara mengucapkan doa-doa suci kepada dang pencipta dan kepada para leluhur yang merupakan suatu simbol fungsi religius.

Berdasarkan uraian diatas, maka dapat disimpulkan bahwa fungsi Religius yang terkandung didalam upacara Tetek Pantan adalah berfungsi untuk membangkitkan nilai-nilai religius dengan dilantunkannya mantra-mantra dan doa-doa suci untuk terciptanya suatu kerukunan, keharmonisan dan cinta kasih. Juga bertujuan untuk meminta restu kepada Sang pencipta Tuhan Yang Maha Esa dan kepada para leluhur dengan mempergunakan berbagai media sarana dan prasarana yang mengandung nilai-nilai sakral dan tentunya kaya akan simbol. Sarana dan berbagai bentuk sesajen yang dipersembahkan pada saat upacara Tetek Pantan tersebut adalah merupakan simbol rasa cinta dan bakti kepada Tuhan dan para leluhur selalu memberikati tamu yang datang serta memberkati anggota masyarakat didaerah tersebut semoga selalu mendapatkan kedamaian dan kebahagiaan.

Upacara Tetek Pantan sebagai wahana atau tempat pembelajaran diri untuk hidup santun dan tatakrama baik dari sikap, berkata, berpikir maupun bertindak dalam kehidupan bermasyarakat.

Berdasarkan dari uraian diatas, maka fungsi etika yang terkandung didalam upacara Tetek Pantan yaitu pikiran, perkataan dan perbuatan atau sikap dalam melaksanaan Upacara Tetek Pantan memberikan fungsi etika bagi masyarakat yang hadir untuk lebih mengerti arti penting sikap santun, ramah tamah, kekeluargaan dalam menyambut tamu yang datang kedaerah mereka sehingga menjadikan contoh yang baik terhadap masyarakat dalam mengimplementasikan dan membiasakan hidup yang saling menghargai dan ramah tamah., berpikir maupun bertindak dalam kehidupan bermasyarakat. 
Fungsi pendidikan bagi masyarakat dalam pelaksanaan Upacara Tetek Pantan adalah peningkatan kecerdasan, tingginya daya serap anak dalam menerima ilmu pengetahuan dan motivasi yang tinggi dalam belajar karena adanya getaran suci atau vibrasi kesucian yang ditimbulkan karena rangsangan atau stimulus mantra dan sarana persembahan dan anak cenderung mempunyai sifat dan karakter yang baik.

\subsection{Makna Upacara Tetek \\ Pantan}

Dalam upacara Pantan adalah merupakan suatu upacara untuk menghormati tamu yang datang di daerah tersebut yang dianggap merupakan tamu kehormatan atau sangat dihormati. Adapun makna dari upacara tetek pantan ini adalah bertujuan untuk memotong, mengusir, menghalau firasat-firasat buruk, mimpi buruk, gangguan penghalang dan rintangan. Sehingga para tamu yang memotong pantan selalu mendapat per perlindungan dari Pencipta Alam Semesta atau
Yang Maha Kuasa, sehingga para tamu tadi mendapat kesehatan, diperpanjangkan umur, dimurahkan rejeki dan dalam menjalankan tugas mendapat kesuksesan.

Dengan dilaksanakannya upacara pantan ini, maka diharapkan agar para tamu tersebut selalu menapatkan lindungan dan berkah dari Yang Maha Kuasa didalam menjalankan tugasnya di daerah tersebut, sehingga tugasnya dapat berjalan baik. Pelaksanaan upacara Pantan di Kabupaten Kotawaringin Timur, dimana didalam pelaksanaannya adalah untuk penyambutan tamu yang dianggap penting dan terhormat.

Upacara Tetek Pantan tersebut di atas yaitu menekankan pada pentingnya persahabatan kepada semua mahluk, dengan mempunyai pandangan yang sama dalam sosial kehidupan masyarakat, sahabat yang sejati adalah teman yang mencintai orang lain seperti ia mencintai dirinya sendiri.

Selanjutnya yang terkandung didalam pelaksanaan Upacara Pantan tersebut sesuai dengan Konsep didalam pepatah Suku Dayak yaitu “ 
Keleh Ketun Penyang Hinje Simpei, Paturung Humba Tamburak" artinya supaya manusia semuanya hiduplah rukun menjadi satu kesatuan yang utuh didalam menghadapi kehidupan ini”. Sesuai dengan konsep pepatah Suku Dayak tersebut maka jelaslah bahwa kehidupan masyarakat suku dayak adalah mencintai kerukunan, kebersamaan tanpa membedamembedakan satu dengan yang lainnya.

Bahwa pelaksanaan upacara Pantan tersebut adalah suatu tindakan yang mengandung nilainilai ritual juga mengandung makna religius yang bertujuan untuk meminta restu kepada Sang pencipta Tuhan Yang Maha Esa dan kepada para leluhur dengan mempergunakan berbagai media sarana dan prasarana yang mengandung nilai-nilai sakral dan tentunya kaya akan simbol. Sarana dan berbagai bentuk sesajen yang dipersembahkan pada saat upacara Tetek Pantan tersebut adalah merupakan simbol rasa cinta dan bakti kepada Tuhan dan para leluhur. Makna religius Upacara Tetek Pantan adalah Upacara yang dilakukan dengan rasa bakti dan kepercayaan yang tinggi tentunya akan bermakna terhadap pengaruh atau membangkitkan rasa Ketuhanan terhadap segala sesuatu yang bersifat sakral, sehingga dengan adanya kasih Tuhan manusia akan merasakan rahmatNya.

Upacara Tetek Pantan tersebut juga bermakna memohonkan kepada Tuhan Yang Maha Kuasa untuk membangkitkan nilai-nilai religius dengan dilantunkannya mantra-mantra dan doa-doa suci untuk terciptanya suatu kerukunan, keharmonisan dan cinta kasih. Juga

\section{Simpulan}

Upacara Pantan dalam pelaksanaan upacara penyambutan tamu tersebut bisa diartikan sebagai pohon penghalang atau kayu perintang, melakukan pemotongan pantan biasanya dipergunakan dalam menyambut tamu-tamu Pejabat atau tamu terhormat dari luar daerah atau menyambut para pahlawan yang baru pulang dari medan peperangan dengan membawa kemenangan.

Acara potong pantan atau tetek pantan adalah memotong, 
mengusir, menghalau firasat-firasat buruk, mimpi buruk, gangguan penghalang dan rintangan. Sehingga para tamu yang memotong pantan selalu mendapat per perlindungan dari Pencipta Alam Semesta atau Yang Maha Kuasa, sehingga para tamu tadi mendapat kesehatan, diperpanjangkan umur, dimurahkan rejeki dan dalam menjalankan tugas mendapat kesuksesan.

\section{Daftar Pustaka}

Adipura, Rudia I Gede Dkk, 2004, Dasar - Dasar Agama Hindu - Lestari Karya Megah, Jakarta.

Departemen Pendidikan dan Kebudayaan Bagian Proyek Pengkajian dan Pembinaan Nilai-nilai Budaya Kalimantan Timur, 1995/1996. Wujud Arti dan Fungsi Puncak-puncak Kebudayaan Lama dan Asli di Kalimantan Timur. Samarinda; Departemen Pendidikan dan Kebudayaan Bagian Proyek Pengkajian dan Pembinaan Nilai-nilai Budaya Kalimantan Timur

Koentjaraningrat, 2002. Pengantar Antropologi Pokok-pokok Etnografi II, Jakarta, Rineka Cipta
Putri ,Vegitya Ramadhani . 2009, Pemaknaan Simbolisme Bahasa Ideologi Dalam Politik - Militer Dalam Pemberitaan Media Massa, http://www.wetpaint.com/

$\begin{array}{llr}\text { Riwut, } & \text { Tjilik .2003. } & \text { Maneser } \\ \text { Panatau Tatu } & \text { Hiang } \\ \text {,Menyelami } & \text { Kekayaan } \\ \text { Leluhur, Pusaka Lima : } & \text { Palangka Raya }\end{array}$

Tim Penyusun, 2005. Kamus Besar Bahasa Indonesia, Balai Pustaka, Jakarta 
